\title{
Population Aspects of Fishes in Geba and Sor Rivers, White Nile System in Ethiopia, East Africa
}

\author{
Simagegnew Melaku, ${ }^{1}$ Abebe Getahun, ${ }^{2}$ and Mulugeta Wakjira ${ }^{3}$ \\ ${ }^{1}$ Department of Biology, Faculty of Natural and Computational Sciences, Metu University, P.O. Box 318, Metu, Ethiopia \\ ${ }^{2}$ Department of Zoological Sciences, College of Natural Sciences, Addis Ababa University, P.O. Box 1176, Addis Ababa, Ethiopia \\ ${ }^{3}$ Department of Biology, College of Natural Sciences, Jimma University, P.O. Box 387, Jimma, Ethiopia
}

Correspondence should be addressed to Mulugeta Wakjira; enku2005@yahoo.com

Received 28 February 2017; Accepted 12 April 2017; Published 11 May 2017

Academic Editor: Stephan Koblmüller

Copyright (C) 2017 Simagegnew Melaku et al. This is an open access article distributed under the Creative Commons Attribution License, which permits unrestricted use, distribution, and reproduction in any medium, provided the original work is properly cited.

\begin{abstract}
This study was carried out to assess the diversity, condition factor, length-weight relationship, and sex ratio of fishes in Geba and Sor Rivers located in Baro-Akobo Basin, White Nile system within Ethiopia. Fish samples were collected in one wet and one dry season. The length-weight relationships were fitted using power equation for the most abundant species. A total of 348 fish specimens were collected using gillnets and hooks. These were identified into eight species and one Garra sp. representing seven genera and four families. Family Cyprinidae was the most dominant with six species (66.7\%). Labeobarbus intermedius, Labeobarbus nedgia, and Labeo cylindricus were the most abundant fish species, respectively, with $60.72 \%, 16.83 \%$, and $14.66 \%$ index of relative importance (IRI). The diversity index was higher for Geba River $\left(H^{\prime}=1.50\right)$ than for Sor River $\left(H^{\prime}=1.10\right)$. All the three most abundant species had negative allometric growth. Seasonal variations in the mean Fulton condition factor (FCF) were statistically significant for $L$. cylindricus $(p<0.05)$. There was variation in the sex ratio with the females dominating in all the three most abundant species. Further investigation into the fish diversity, food, feeding, and reproductive behaviors of fish species especially in the tributaries of these rivers and their socioeconomic aspects is recommended.
\end{abstract}

\section{Introduction}

Ethiopia could be called the "water tower of northeastern Africa" on a continent where aridity is the rule. Ethiopia is rich in inland water bodies with diversified fish species composed of Nilo-Sudanic, East African, and endemic forms $[1,2]$. A review by Tedla [3] listed 93 fish species for the entire Ethiopian freshwater system. A survey by Getahun and Stiassny [4] identified 65 species belonging to 19 genera and 9 families. Later on, reviews by Getahun [5, 6] listed up to 153 valid indigenous fish species and subspecies in 25 families for the Ethiopian freshwater systems. A more recent survey by Golubstov and Darkov [7] provided a basin-wide summary of the nation's ichthyofaunal diversity. According to this work, the nation's major basins, namely, Baro-Akobo (White Nile within Ethiopia), Abay (Blue Nile within Ethiopia), OmoTurkana, Tekeze-Atbara, Shebelle-Genale, and Rift Valley basins, respectively, have $113,77,76-79,34,33$, and 28-31 fish species. Even so, a study on the diversity of the Ethiopian fish fauna still remains far from complete largely owing to the large expanse of its geography (i.e., 1.1 million $\mathrm{km}^{2}$ total area) and limited surveys. Many of the drainage basins, especially the rivers, are not exhaustively explored [6]. Geba and Sor Rivers are among such rivers that lack exhaustive studies on the diversity and associated biological characters of their fish fauna. Thus, the present study was undertaken to address this gap, and as such it represents a baseline study on the diversity, relative abundance, and some biological characteristics of fishes in the rivers addressed in the present study, in an effort to contribute to any conservation attempts of their fish fauna.

\section{Materials and Methods}

2.1. Description of the Study Area. The study was conducted in Geba and Sor Rivers located in Yayu and Metu Districts 


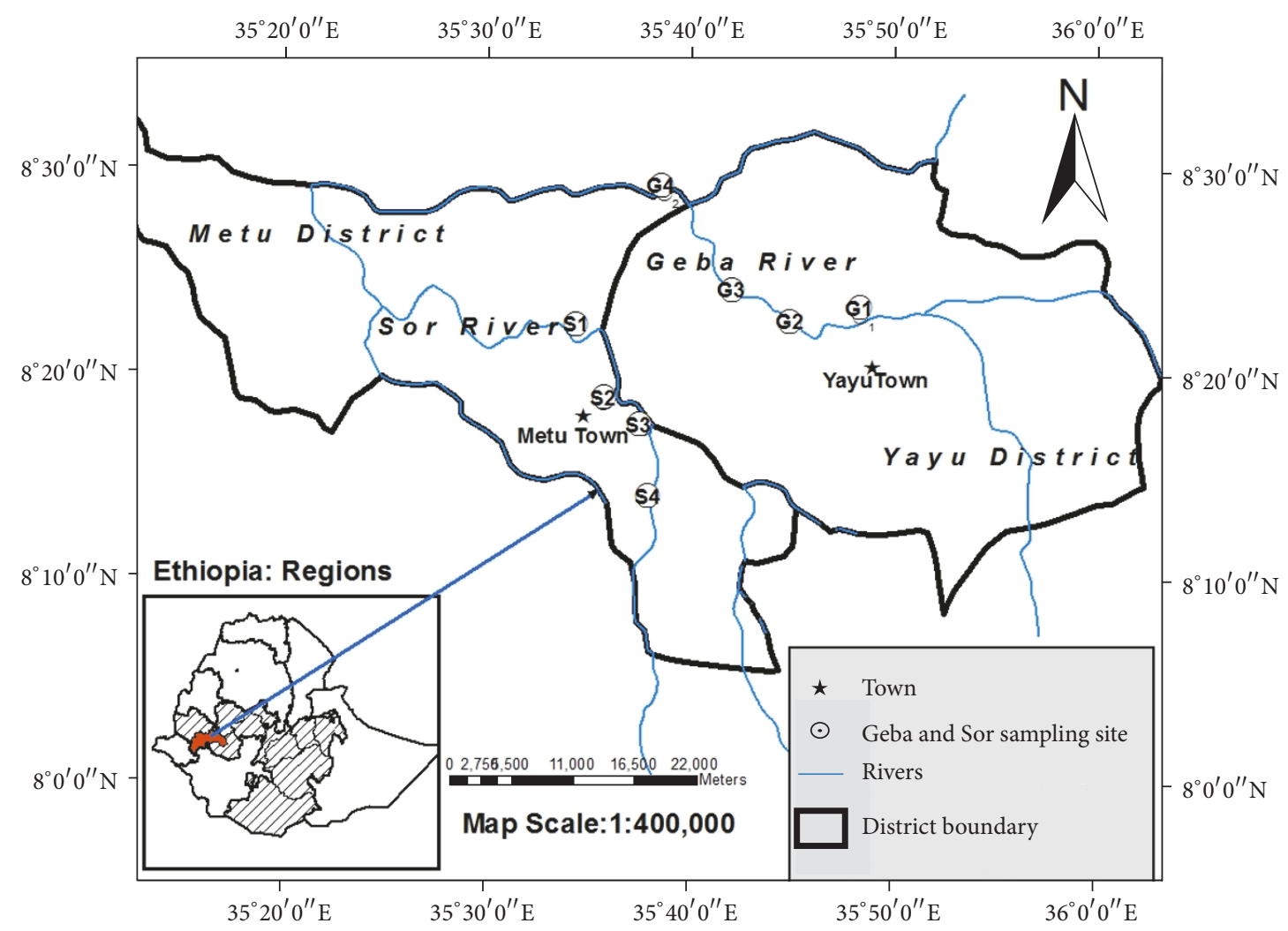

FIGURE 1: Map of the study sites and rivers.

of Ilu Aba-Bor Zone, Oromia Regional State in southwestern Ethiopia (Figure 1). The districts are located at $550 \mathrm{~km}$ and $600 \mathrm{~km}$ southwest of the capital Addis Ababa, respectively. The annual temperature ranges from 14.13 to $29.07^{\circ} \mathrm{C}$ and 11.21 to $27.33^{\circ} \mathrm{C}$ for Yayu and Metu Districts, respectively. The mean annual rainfall is $1563 \mathrm{~mm} /$ year for Yayu District and $1427.17 \mathrm{~mm} /$ year for Metu District, with high variation from year to year. The rainfall patterns of the districts are unimodal, with low rainfall during January and February and the highest rainfall between June and August [8]. Ficus species, Coffea arabica, Croton macrostachyus, and Schefflera abyssinica are among the frequently observed vegetation in the area.

2.2. Sampling Sites. Eight sampling sites were selected from both rivers based on flow nature and accessibility (Figure 1). The basic habitat characteristics and geographical locations of the sampling sites are summarized in Table 1. The Sor River sampling sites are located relatively at higher altitude ( $>1500 \mathrm{~m}$ above sea level) than the Geba River sites which are located below $1300 \mathrm{~m}$ above sea level. The channel diameter of the sampling sites ranged from 29 to $40 \mathrm{~m}$ with a mean value of $33.21 \mathrm{~m}$. All the sampling sites, except the Hora site on Sor River (S1), had clear water with sandy, gravel, and rocky bottom. Hora site was turbid with largely muddy bottom. Most parts of the Sor River were highly irrigated and had less vegetation cover.

2.3. Fish Sampling and Identification. Fish samples were collected during one wet season and one dry season between
October 2012 and March 2013. Fish specimens were collected using gillnets of various mesh sizes $(12,16,20$, and $24 \mathrm{~cm}$ stretched mesh) and hooks. Gillnets were set late in the afternoon and collected early in the morning the next day. The same extent of fishing effort was used across the seasons and sites. Field-level identification of the fish specimens was made to species level using relevant taxonomic literature [3, 9-12]. Total length (TL) and total weight (TW) measurements were taken, to the nearest $0.1 \mathrm{~cm}$ and $0.1 \mathrm{~g}$, respectively. Ultimately, voucher specimens from each species were preserved in $10 \%$ formalin solution and transported to the Department of Biology, Jimma University, where they are deposited.

2.4. Data Analysis. Shannon diversity index $\left(H^{\prime}\right)$ [13] was used for assessing the diversity of fish species for each sampling site and the rivers as follows:

$$
H^{\prime}=-\sum_{i=1}^{S} \frac{\mathrm{ni}}{N} \ln \left(\frac{\mathrm{ni}}{N}\right)
$$

where $\sum$ is the sum from species 1 to $S$; ni is the number of individuals of species " $i$ "; $N$ is the total number of individuals of all species; $S$ is species richness.

Estimation of the relative abundance of fishes in the study rivers was made by comparing the relative catch in number and weight in the total sampling. An index of relative importance (IRI), which is a measure of the relative abundance or commonness of the species based on number 
TABLE 1: Summary of the sampling sites and rivers; asl: above sea level.

\begin{tabular}{|c|c|c|c|c|c|}
\hline River & Site & Habitat type & Width (m) & $\begin{array}{l}\text { Altitude } \\
(\mathrm{m}, \mathrm{asl})\end{array}$ & Coordinates \\
\hline \multirow{4}{*}{ Sor } & Hora site (S1) & $\begin{array}{l}\text { Turbid water, gravel and } \\
\text { muddy }\end{array}$ & 32 & 1552 & $\begin{array}{l}\mathrm{N} 8^{\circ} 22^{\prime} 45^{\prime \prime} \\
\mathrm{E} 35^{\circ} 32^{\prime} 42^{\prime \prime}\end{array}$ \\
\hline & $\begin{array}{c}\text { At the bridge from Metu to } \\
\text { Hurumu (S2) }\end{array}$ & $\begin{array}{c}\text { Clear water, gravel, sandy, } \\
\text { and rocky }\end{array}$ & 30 & 1554 & $\begin{array}{l}\mathrm{N} 8^{\circ} 20^{\prime} 13^{\prime \prime} \\
\mathrm{E} 35^{\circ} 35^{\prime} 47^{\prime \prime}\end{array}$ \\
\hline & Lakata site (S3) & $\begin{array}{c}\text { Clear water, gravel and } \\
\text { rocky }\end{array}$ & 33 & 1554 & $\begin{array}{l}\mathrm{N} 8^{\circ} 18^{\prime} 27^{\prime \prime} \\
\mathrm{E} 35^{\circ} 37^{\prime} 38^{\prime \prime}\end{array}$ \\
\hline & Moges site (S4) & $\begin{array}{c}\text { Clear water, gravel and } \\
\text { rocky }\end{array}$ & 33.7 & 1556 & $\begin{array}{l}\mathrm{N} 8^{\circ} 13^{\prime} 33^{\prime \prime} \\
\mathrm{E} 35^{\circ} 38^{\prime} 55^{\prime \prime}\end{array}$ \\
\hline \multirow{4}{*}{ Geba } & Doko site (G1) & $\begin{array}{c}\text { Clear water, gravel and } \\
\text { rocky }\end{array}$ & 35 & 1241 & $\begin{array}{l}\mathrm{N} 8^{\circ} 23^{\prime} 42^{\prime \prime} \\
\mathrm{E} 35^{\circ} 49^{\prime} 23^{\prime \prime}\end{array}$ \\
\hline & $\begin{array}{l}\text { At the bridge from Yayu to } \\
\text { Doreni District (G2) }\end{array}$ & $\begin{array}{c}\text { Clear water, gravel and } \\
\text { rocky }\end{array}$ & 33 & 1252 & $\begin{array}{l}\mathrm{N} 8^{\circ} 22^{\prime} 59^{\prime \prime} \\
\mathrm{E} 35^{\circ} 46^{\prime} 29^{\prime \prime}\end{array}$ \\
\hline & $\begin{array}{l}\text { Down the bridge from Yayu } \\
\text { to Doreni District (G3) }\end{array}$ & $\begin{array}{c}\text { Clear water, gravel, sandy, } \\
\text { and rocky }\end{array}$ & 40 & $1254 \mathrm{~m}$ & $\begin{array}{l}\mathrm{N} 8^{\circ} 24^{\prime} 58^{\prime \prime} \\
\mathrm{E} 35^{\circ} 42^{\prime} 52^{\prime \prime}\end{array}$ \\
\hline & $\begin{array}{l}\text { At the bridge from Metu to } \\
\text { Alge District (G4) }\end{array}$ & $\begin{array}{c}\text { Clear water, gravel and } \\
\text { rocky }\end{array}$ & 29 & $1149 \mathrm{~m}$ & $\begin{array}{l}\mathrm{N} 8^{\circ} 30^{\prime} 16^{\prime \prime} \\
\mathrm{E} 35^{\circ} 38^{\prime} 53^{\prime \prime}\end{array}$ \\
\hline
\end{tabular}

and weight of individuals in catches, as well as their frequency of occurrence $[14,15]$, was computed as

$$
\% \operatorname{IRI}=\frac{\left(\% W_{i}+\% N_{i}\right) \times \% F_{i}}{\sum_{j=1}^{S}\left(\% W_{j}+\% N_{j}\right) \times \% F_{j}} \times 100,
$$

where $j$ is 1 to $S$; $\% W_{i}$ and $\% N_{i}$ are percentage weight and number of each species of total catch, respectively; $\% F_{i}$ is percentage frequency of occurrence of each species in total samplings; $\% W_{j}$ and $\% N_{j}$ are percentage weight and number of total species of total catch, respectively; $\% F_{j}$ is percentage frequency of occurrence of total species in total number of samplings; and $S$ is the total number of species.

The relationship between total length and total weight of the dominant fish species, namely, Labeobarbus intermedius, Labeobarbus nedgia, and Labeo cylindricus, was fitted using power function [16] as

$$
\mathrm{TW}=a \mathrm{TL}^{b},
$$

where TW is total weight $(\mathrm{g})$, TL is total length $(\mathrm{cm})$, and " $a$ " and " $b$ " are the constant and power coefficients, respectively, of the regression line.

The well-being of fishes of the study rivers was investigated for the three most abundant species using Fulton condition factor (FCF) $[16,17]$, computed as

$$
\mathrm{FCF}=\frac{\mathrm{TW}}{\mathrm{TL}^{3}} \times 100,
$$

where TW is total weight $(\mathrm{g})$ and TL is total length $(\mathrm{cm})$.

The sex ratio for the three dominant species was determined using the equation

$$
\text { Sex ratio }=\frac{\text { number of females }}{\text { number of males }} \text {. }
$$

Significant variation in FCF between seasons was tested using one-way analysis of variance (ANOVA), whereas significant variation in sex ratio was tested using Chi-square at 5\% level of significance in SPSS for Windows (ver. 16).

\section{Results and Discussion}

3.1. Fish Species Diversity and Distribution. A total of eight species and one Garra sp. representing seven genera and four families were identified from Geba and Sor Rivers during the study period (Figure 2). The identity of a single Garra specimen collected from Sor River could not be determined using the existing keys [3, 9-12]. This specimen has much resemblance to the Garra specimens reported from the same river by Golubtsov et al. [18] and discussed as being potentially undescribed. It thus calls for further collection of sufficient samples for possible description in the future. Labeo forskalii, Raiamas senegalensis, Bagrus docmak, and Mormyrus hasselquistii were collected only from Geba River while Oreochromis niloticus and Garra sp. were collected only from Sor River. Labeobarbus intermedius, Labeobarbus nedgia, and Labeo cylindricus were recorded from both rivers. There was variation in diversity between the two rivers as the Shannon diversity index was higher for Geba River $\left(H^{\prime}\right.$ $=1.50)$ and lower for Sor River $\left(H^{\prime}=1.10\right)$.

The diversity of fish fauna identified from the studied rivers contains a mixture of Nilo-Sudanic ( $L$. forskalii, $L$. cylindricus, B. docmak, and M. hasselquistii) and East African forms (L. intermedius, L. nedgia, O. niloticus, and Garra sp.). The Nilo-Sudanic forms were the dominant forms in terms of diversity and are represented by a large number of species found in the Baro-Akobo Basin [6]. This could be probably because of the connection between the White Nile and the two rivers $[2,7,10]$. Only one species endemic to Ethiopia ( $L$. nedgia) was recorded from the two rivers and it is the first report for Baro-Akobo Basin. 


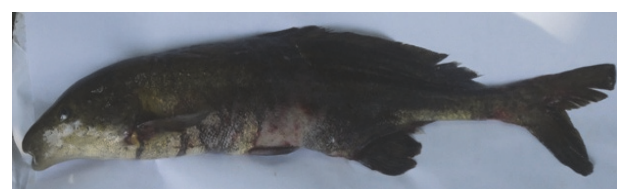

(a)

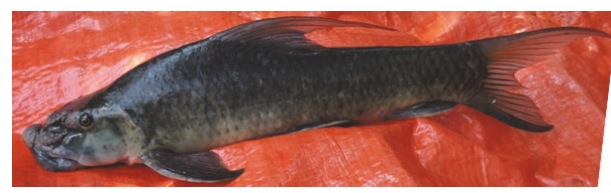

(c)

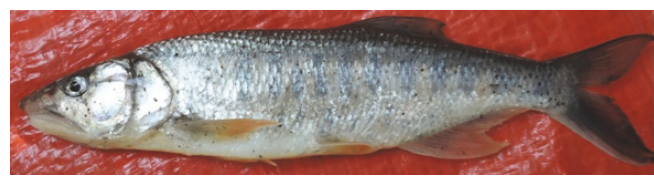

(e)

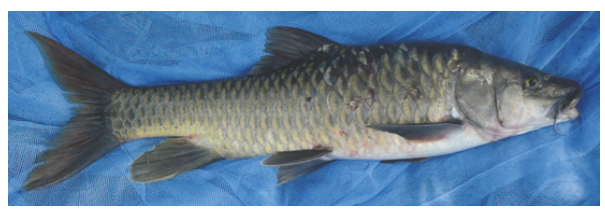

(g)

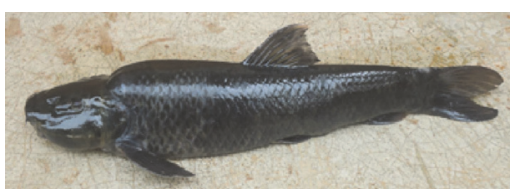

(b)

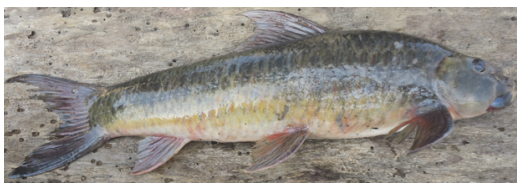

(d)

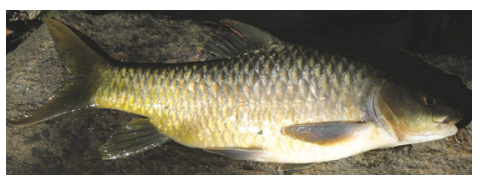

(f)

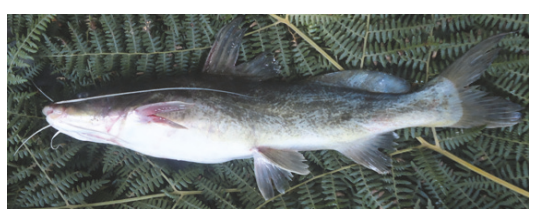

(h)

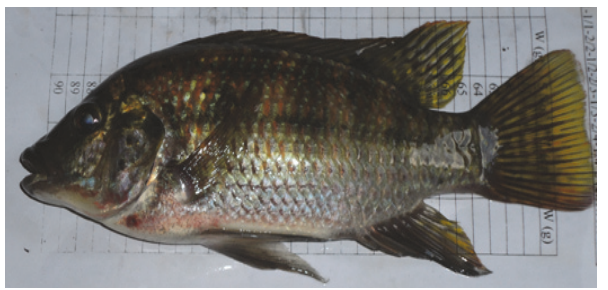

(i)

FIgURE 2: Fish species identified from Geba and Sor Rivers during the present study; (a) Mormyrus hasselquistii (Mormyridae), (b) Garra sp., (c) Labeo forskalii, (d) Labeo cylindricus, (e) Raiamas senegalensis, (f) Labeobarbus intermedius, (g) Labeobarbus nedgia (Cyprinidae, b-g), (h) Bagrus docmak (Bagridae), and (i) Oreochromis niloticus (Cichlidae).

3.2. Relative Abundance. A total of 348 fish specimens were collected from eight sampling sites during the study period. Of the total specimens collected, 116 were caught during the wet season and 232 specimens were caught during the dry season. Labeobarbus intermedius was the most abundant species in number $(47.13 \%)$ during both the wet and the dry seasons followed, respectively, by L. cylindricus (21.84\%), L. forskalii (12.36\%), and L. nedgia (12.36\%). Raiamas senegalensis, M. hasselquistii, and Garra sp. were the least abundant fish species in number represented by one specimen each (Table 2). Based on the index of relative importance (IRI), which more or less concurred with the numeric abundance, the most important species in the total catches were $L$. intermedius (48.62\%), L. nedgia (16.81\%), and L. cylindricus (14.76\%) (Table 2).

In both rivers, the weight and number of fish specimens were higher in the dry season than in the wet season (Table 3). That fewer fish were caught during the wet season might be due to high turbidity, speedy run-off, and low temperature [19]. There is also higher water discharge during the wet
TABLE 2: Summary of the percent number $(\% N)$, percent weight $(\% W)$, and \% index of relative abundance (\% IRI) of fish species of Geba and Sor Rivers. Total number of specimens $(N)=348$.

\begin{tabular}{lccc}
\hline Species & $\% N$ & $\% W$ & $\%$ IRI \\
\hline Labeobarbus intermedius & 47.13 & 48.62 & $\mathbf{6 0 . 7 2}$ \\
Labeo cylindricus & 21.84 & 15.15 & $\mathbf{1 4 . 6 6}$ \\
Labeobarbus nedgia & 12.36 & 15.94 & $\mathbf{1 6 . 8 3}$ \\
Labeo forskalii & 12.36 & 12.96 & 6.02 \\
Oreochromis niloticus & 2.87 & 1.25 & 0.49 \\
Bagrus docmak & 2.01 & 5.54 & 1.20 \\
Raiamas senegalensis & 0.86 & 0.24 & 0.043 \\
Garra sp. & 0.29 & 0.18 & 0.018 \\
Mormyrus hasselquistii & 0.29 & 0.12 & 0.016 \\
\hline
\end{tabular}

season, so fishes could be highly dispersed in the large volume of water, than during the dry season, and it thus becomes difficult to catch them [20]. In addition, the variation in 
TABLE 3: Summary of the weight (g) of fish species for each season.

\begin{tabular}{|c|c|c|c|c|c|c|c|c|c|c|}
\hline \multirow{2}{*}{ Fish species } & \multicolumn{4}{|c|}{ Wet season } & \multicolumn{4}{|c|}{ Dry season } & \multicolumn{2}{|c|}{ Overall } \\
\hline & Geba & Sor & Total & $\%$ & Geba & Sor & Total & $\%$ & Total & $\%$ \\
\hline L. intermedius & 24.30 & 6.00 & 30.30 & 50.25 & 31.80 & 17.60 & 49.40 & 47.48 & 79.70 & 48.62 \\
\hline L. cylindricus & 3.20 & 4.30 & 7.50 & 12.44 & 10.45 & 6.95 & 17.40 & 16.72 & 24.90 & 15.15 \\
\hline L. nedgia & 12.40 & 3.20 & 15.60 & 25.87 & 7.15 & 3.45 & 10.60 & 10.19 & 26.20 & 15.94 \\
\hline L. forskalii & 5.70 & - & 5.70 & 9.45 & 15.60 & - & 15.60 & 14.99 & 21.30 & 12.96 \\
\hline O. niloticus & - & 0.70 & 0.70 & 1.16 & - & 1.35 & 1.35 & 1.30 & 2.05 & 1.25 \\
\hline B. docmak & - & - & - & - & 9.10 & - & 9.10 & 8.75 & 9.10 & 5.54 \\
\hline R. senegalensis & - & - & - & - & - & - & - & - & 0.40 & 0.24 \\
\hline Garra sp. & - & - & - & - & - & 0.30 & 0.30 & 0.29 & 0.30 & 0.18 \\
\hline M. hasselquistii & - & - & - & - & 0.20 & - & 0.20 & 0.19 & 0.20 & 0.12 \\
\hline
\end{tabular}

TABLE 4: Length-weight relationship of the most common fish species of Geba and Sor Rivers (ANOVA, $p<0.05$ ); $N=$ total number of specimens.

\begin{tabular}{|c|c|c|c|c|c|c|c|}
\hline Species & Rivers & $\mathrm{TW}=a \mathrm{TL}^{b}$ & $R^{2}$ & $p$ & Mean \pm SE TL & Mean \pm SE TW & $N$ \\
\hline \multirow{2}{*}{ L. intermedius } & Geba & $0.035 \mathrm{TL}^{2.70}$ & 0.97 & 0.00 & $38.48 \pm 1.40$ & $813.04 \pm 89.50$ & 69 \\
\hline & Sor & $0.013 \mathrm{TL}^{2.27}$ & 0.79 & 0.00 & $26.68 \pm 0.55$ & $249.47 \pm 21.36$ & 95 \\
\hline \multirow{2}{*}{ L. nedgia } & Geba & $0.049 \mathrm{TL}^{2.60}$ & 0.97 & 0.00 & $43.6 \pm 2.32$ & $977.5 \pm 123.99$ & 20 \\
\hline & Sor & $0.026 \mathrm{TL}^{2.70}$ & 0.79 & 0.00 & $27.61 \pm 1.24$ & $289.13 \pm 58.80$ & 23 \\
\hline \multirow{2}{*}{ L. cylindricus } & Geba & $0.051 \mathrm{TL}^{2.56}$ & 0.92 & 0.00 & $28.52 \pm 0.73$ & $284.37 \pm 20.90$ & 48 \\
\hline & Sor & $0.236 \mathrm{TL}^{2.88}$ & 0.68 & 0.00 & $31.21 \pm 0.52$ & $401.78 \pm 22.04$ & 28 \\
\hline
\end{tabular}

gillnet efficiency might have contributed to variation in the catches between wet and dry seasons. Moreover, leaves, logs, and roots that were brought by flooding could decrease the efficiency of gillnets during the wet season.

The number and weight of fish specimens in Geba River are higher than in Sor River. The difference in number and weight of fish specimens in these rivers might be attributed to the less vegetation cover and widespread irrigation development in most parts of Sor River. This, in turn, may have contributed to the lack of good habitats with diverse riparian vegetation.

3.3. Length-Weight Relationship. Length-weight relationship of the three most abundant species, L. intermedius, L. nedgia, and L. cylindricus, showed negative allometric growth. The $b$-value for L. cylindricus (2.72) is comparable with the value (2.76) reported from Angereb and Sanja Rivers, Tekeze Basin [20]. The $b$-values are relatively lower for $L$. intermedius (2.50) and L. nedgia (2.65) (Table 4) when compared with the values reported for these species from Angereb River (L. intermedius: 2.96; L. nedgia: 2.94) [20] and from ArnoGarno River (L. intermedius: 2.95; L. nedgia: 2.98) [21]. The variations in the results between the present study and those studies could be ascribed to the differences in the number of samples, the differences in food availability, stage of fish gonad development, and spawning period [16].

3.4. Fulton Condition Factor (FCF). Fish conditions depend on biological factors such as the age and environmental or geographical and temporal factors such as the season of the year when samples are collected [22-24]. Generally, higher condition is associated with high energy content, adequate food availability, reproductive potential, and favorable environmental conditions [25]. The mean FCF value for $L$. intermedius (1.21) (Table 5) is comparable to the value (1.23) reported for Borkena River in Awash Basin [26]. The mean FCF value for L. nedgia (1.05) from Geba and Sor Rivers was lower than the value (1.48) reported for Angereb and Sanja Rivers in Tekeze Basin [20]. However, the FCF values for $L$. intermedius were higher than the value (1.0) reported for the same species from Beles and Gilgel-Beles Rivers [27] as well as the value (1.12) reported from Guang, Ayima, Gendwuha, and Shinfa Rivers [28]. The mean FCF value for L. cylindricus (1.21) was higher than the value (1.18) reported for Angereb and Sanja Rivers in Tekeze Basin [20]. The main reason for the differences observed in the mean FCF between the present and past studies might relate to the variation in the extent of sampling or variations in the factors such as food quantity and quality, water level and flow rate, feeding rate, health, and reproductive activity of fishes in the study areas $[29,30]$. Statistically significant seasonal variation was observed for $L$. cylindricus (Table 5).

3.5. Sex Ratio. The sex ratio for the three most abundant fish species, namely, L. intermedius, L. nedgia, and L. cylindricus, is provided in Table 6 . There was variation in sex ratio with the females dominating in all the three species. However, the Chisquare test showed that there was no significant difference 
TABLE 5: Summary of the Fulton condition factor for the most abundant species of Geba and Sor Rivers; SE is the standard error of the mean; $N$ is the total number of the specimens; * indicates statistically significant variation at $5 \%$.

\begin{tabular}{|c|c|c|c|c|c|c|}
\hline \multirow{2}{*}{ Species } & \multirow{2}{*}{$\begin{array}{l}\text { Wet season } \\
\text { Mean } \pm \text { SE }\end{array}$} & \multirow{2}{*}{$N$} & \multirow{2}{*}{$\begin{array}{l}\text { Dry season } \\
\text { Mean } \pm \text { SE }\end{array}$} & \multirow{2}{*}{$N$} & \multicolumn{2}{|c|}{ ANOVA } \\
\hline & & & & & $F$ & $p$ \\
\hline L. intermedius & $1.20 \pm 0.06$ & 50 & $1.22 \pm 0.03$ & 114 & 0.127 & 0.722 \\
\hline L. cylindricus & $1.10 \pm 0.05$ & 20 & $1.25 \pm 0.02$ & 56 & 9.954 & $0.002^{*}$ \\
\hline L. nedgia & $1.03 \pm 0.03$ & 25 & $1.09 \pm 0.05$ & 18 & 1.109 & 0.299 \\
\hline
\end{tabular}

TABLE 6: Summary of sex ratio for the most abundant species of Geba and Sor Rivers.

\begin{tabular}{lcccc}
\hline Number & Fish species & Females (F) & Males (M) & F: M ratio \\
\hline 1 & L. intermedius & 85 & 75 & $1: 0.88$ \\
2 & L. nedgia & 26 & 17 & $1: 0.65$ \\
3 & L. cylindricus & 44 & 32 & $1: 0.72$ \\
\hline
\end{tabular}

between the numbers of males and females $\left(\chi^{2}, p>0.05\right)$. The difference in sex ratio might be due to variation in the two sexes in their vulnerability to the fishing gears used, fishing sites, habitat, and segregation during spawning and feeding [31].

\section{Conclusion}

In the present collections, eight species and one Garra sp. representing seven genera and four families were identified from Geba and Sor Rivers, Baro-Akobo Basin, White Nile system within Ethiopia. Fish diversity of the two rivers appeared to be low as compared to the other most studied rivers in Ethiopia. The fish faunal diversity of both rivers was dominated by cyprinid fish species with $L$. intermedius, $L$. nedgia, and $L$. cylindricus being the most abundant fish species, respectively. Studies are needed on food and feeding, reproductive behaviors of fish species, and fisheries socioeconomic aspects of the two rivers.

\section{Conflicts of Interest}

The authors declare that there are no conflicts of interest regarding the publication of this paper.

\section{Acknowledgments}

The authors would like to thank Jimma University for the financial support.

\section{References}

[1] R. B. Wood and J. F. Talling, "Chemical and algal relationships in a salinity series of Ethiopian inland waters," Hydrobiologia, vol. 158, no. 1, pp. 29-67, 1988.

[2] T. R. Roberts, "Geographical distribution of African freshwater fishes," Zoological Journal of the Linnean Society, vol. 57, no. 4, pp. 249-319, 1975.

[3] S. Tedla, Freshwater Fishes of Ethiopia, Department of Biology, Addis Ababa University, Addis Ababa, Ethiopia, 1973.
[4] A. Getahun and M. Stiassny, "The freshwater biodiversity crisis: the case of the Ethiopian fish fauna," SINET: Ethiopian Journal of Science, vol. 21, no. 2, pp. 207-230, 1998.

[5] A. Getahun, "The nile in the Ethiopian territory: Riverine fish and fisheries," in Proceedings of the Food and Water Challenge International Workshop, Addis Ababa, Ethiopia, 2003.

[6] A. Getahun, "An overview of diversity and conservation status of the Ethiopian freshwater fish fauna," Journal of Afrotropical Zoology, special volume, pp. 87-96, 2007.

[7] A. Golubstov and A. Darkov, "A review of Fish Diversity in the main Drainage systems of Ethiopia," in Ecological and Faunistic Studies in Ethiopia, S. Dmitry, Pavlov, Y. Dgebuadge, A. Andrey, and M. Mina, Eds., JERBE 20 Years Scientific Cooperation, Artistic inc, Addis Ababa, Ethiopia, 2008.

[8] National Metrological Agency Jimma Branch, Jimma, 2013.

[9] G. Boulenger, Catalogue of the Freshwater Fishes of Africa, vol. 1-4, British Museum of Natural History, London, UK, 1909-1916.

[10] A. Golubtsov, A. Darkov, Y. Y. Dgebuadze, and M. Mina, An Artificial Key to Fish Species of the Gambela Region (The White Nile Basin in the Limits of Ethiopia), Joint Ethio-Russian Biological Expedition. Artistic Printing Enterprise, Addis Ababa, Ethiopia, 1995.

[11] M. L. J. Stiassny and A. Getahun, "An overview of labeonin relationships and the phylogenetic placement of the Afro-Asian genus Garra Hamilton, 1922 (Teleostei: Cyprinidae), with the description of five new species of Garra from Ethiopia, and a key to all African species," Zoological Journal of the Linnean Society, vol. 150, no. 1, pp. 41-83, 2007.

[12] R. Habteselassie, Fishes of Ethiopia. Annotated Checklist with Pictorial Identification Guide, Ethiopian Fisheries and Aquatic Science Association, Addis Ababa, Ethiopia, 2012.

[13] M. Begon, J. Harper, and C. Townsend, Ecology: Individuals, Populations and Communities, Blackwell Scientific Publications, 2nd edition, 1990.

[14] J. Kolding, The fish resource of Lake Turkana and their environment [Cand. Scient. thesis], University of Bergen, Norway, 1989.

[15] J. Kolding, PASGEAR. A Data Base Package for Experimental or Artisanal Fishery Data from Passive Gears. An Introductory Manual, University of Bergen, Department of Fisheries and Marine Biology, 1999.

[16] T. Bagenal and F. Tesch, "Age and growth," in Methods for Assessment of Fish Production in Fresh Waters, T. B. Bageal, Ed., pp. 101-136, Black well, New York, NY, USA, 1978.

[17] G. Lecren, "The length-weight relationship and seasonal cycle in gonad weight and condition in the perch (Perca fluviatilis)," Journal of Animal Ecology, vol. 20, pp. 201-219, 1951.

[18] A. S. Golubtsov, S. E. Cherenkov, and F. Tefera, "High morphological diversity of the genus Garra in the Sore River (the White Nile Basin, Ethiopia): one more cyprinid species flock?" Journal of Ichthyology, vol. 52, no. 11, pp. 817-820, 2012. 
[19] C. A. Nsor and E. A. Obodai, "Environmental determinants influencing fish community structure and diversity in two distinct seasons among wetlands of northern region (Ghana)," International Journal of Ecology, vol. 2016, Article ID 1598701, 10 pages, 2016.

[20] G. Tesfaye, Diversity, relative abundance and biology of fishes in Angereb and Sanja Rivers, Tekeze basin, Ethiopia [M.S. thesis], Addis Ababa University, Addis Ababa, Ethiopia, 2006.

[21] S. Gebremedhin, pawning migration of Labeobarbus species of Lake Tana to Arno-Garno River, Blue Nile Basin, Ethiopia [M.S. thesis], Bahir Dar University, Bahir Dar, Ethiopia, 2011.

[22] S. Ferreira, R. Sousa, J. Delgado, D. Carvalho, and T. Chada, "Weight-length relationships for demersal fish species caught off the Madeira archipelago (eastern-central Atlantic)," Journal of Applied Ichthyology, vol. 24, no. 1, pp. 93-95, 2008.

[23] A. Vaslet, Y. Bouchon-Navaro, M. Louis, and C. Bouchon, "Weight-length relationships for 20 fish species collected in the mangroves of Guadeloupe (Lesser Antilles)," Journal of Applied Ichthyology, vol. 24, no. 1, pp. 99-100, 2008.

[24] M. Nowak, W. Popek, W. Jagusiak et al., "Weight-length relationships for three fishes (Leuciscus leuciscus, Phoxinus phoxinus, Salmo trutta) from the Strwiaz River (Dniester River drainage)," Archives of Polish Fisheries, vol. 17, no. 4, pp. 313-316, 2009.

[25] C. Paukert and R. S. Rogers, "Factors affecting condition of flannelmouth suckers in the Colorado River, Grand Canyon, Arizona," North American Journal of Fisheries Management, vol. 24, no. 2, pp. 648-653, 2004.

[26] A. Tessema, M. Mingist, and E. Dejen, "Diversity, relative abundance and biology of fishes in Borkena and Mille Rivers, Awash Basin, Ethiopia," Journal of Fisheries International, vol. 7, no. 3-6, pp. 70-76, 2012.

[27] Z. Berie, Diversity, relative abundance and biology of fishes in Beles and Gilgel-Beles Rivers, Abay basin, Ethiopia [M.S. thesis], Addis Ababa University, Addis Ababa, Ethiopia, 2007.

[28] D. Tewabe, Diversity, relative abundance and Biology of fishes in Gendwuha, Guang, Shinfa and Ayima Rivers, North Gonder Ethiopia [M.Sc Thesis], Addis Ababa University, Addis Ababa, Ethiopia, 2008.

[29] A. Payne, Ecology of Tropical Lakes and Rivers, John Ailey \& Sons, Chichester, UK, 1986.

[30] G. Tefera, Food, nutrition and digestive efficiency in Oreochromis niloticus L. (Pisces: Cichlidae) in Lake Awassa, Ethiopia [Ph.D. thesis], University of Waterloo, Ontario, Canada, 1987.

[31] D. Admassu, "Maturity, fecundity brood size and sex ratio of Tilapia (Oreochromis niloticus) in Lake Awasa, Ethiopia," SINET: Ethiopian Journal of Sciences, vol. 17, no. 1, pp. 53-69, 1994. 

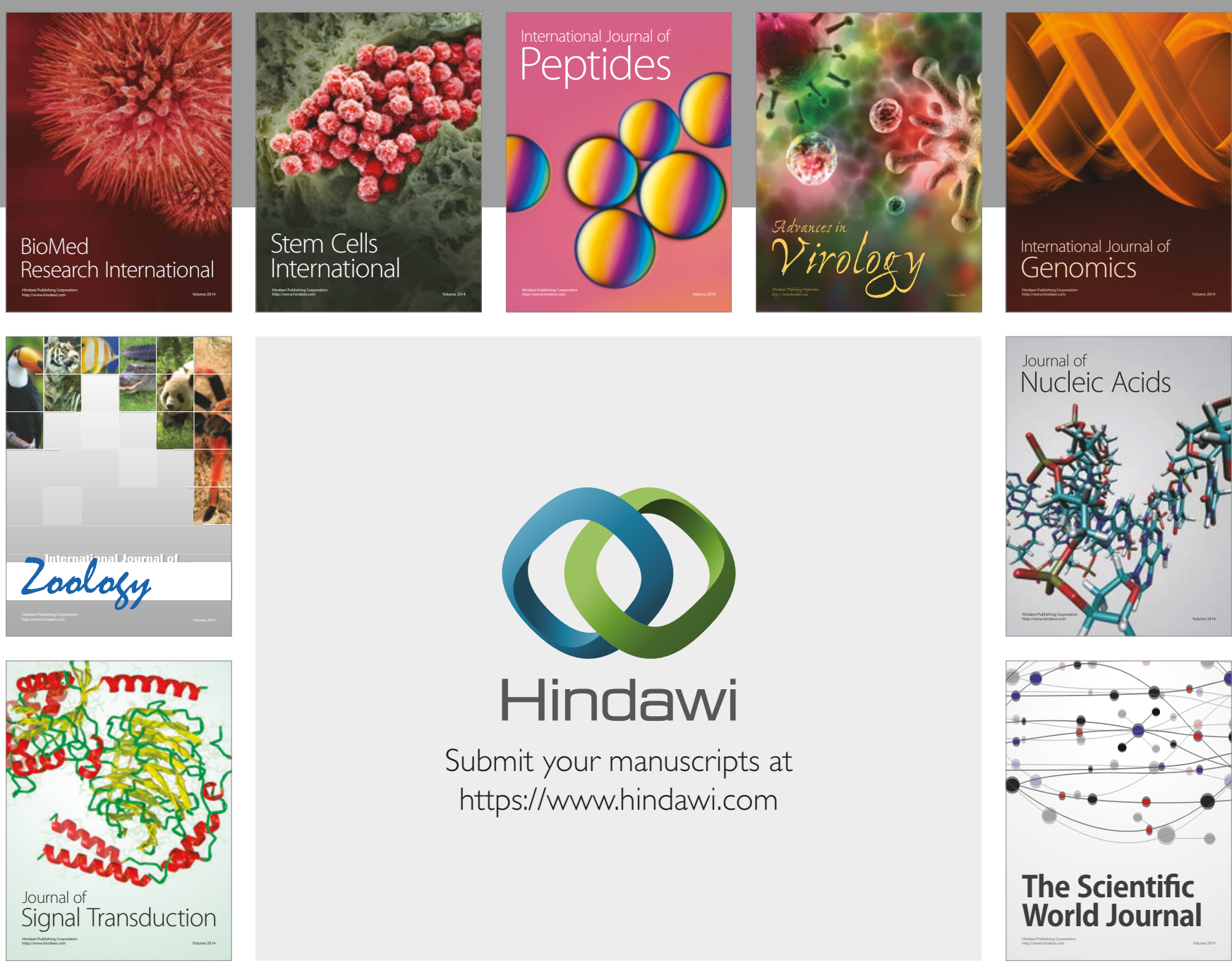

Submit your manuscripts at

https://www.hindawi.com
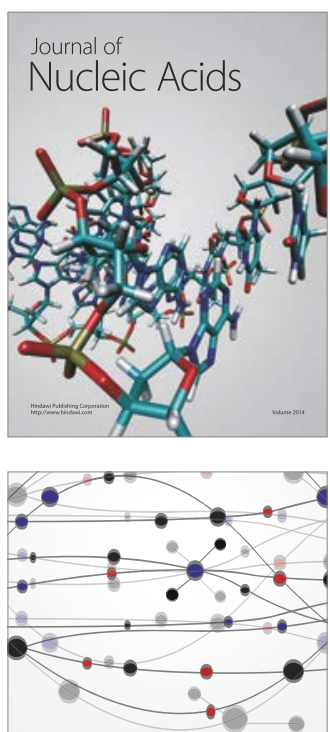

The Scientific World Journal

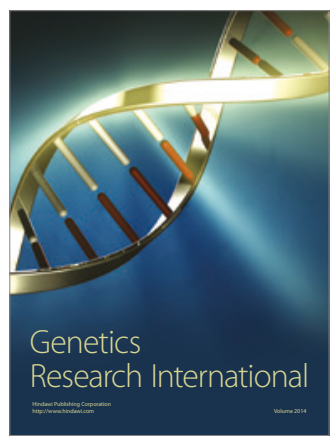

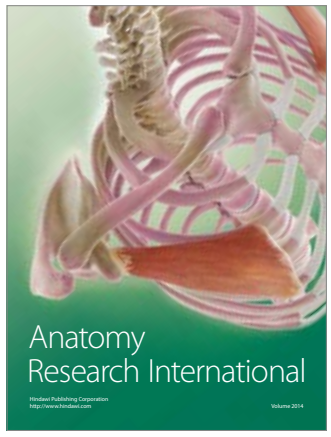

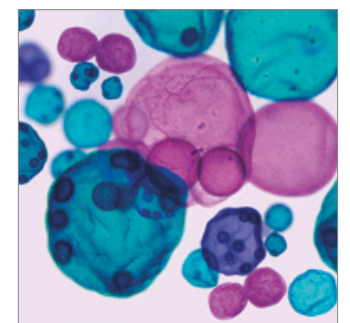

International Journal of Microbiology
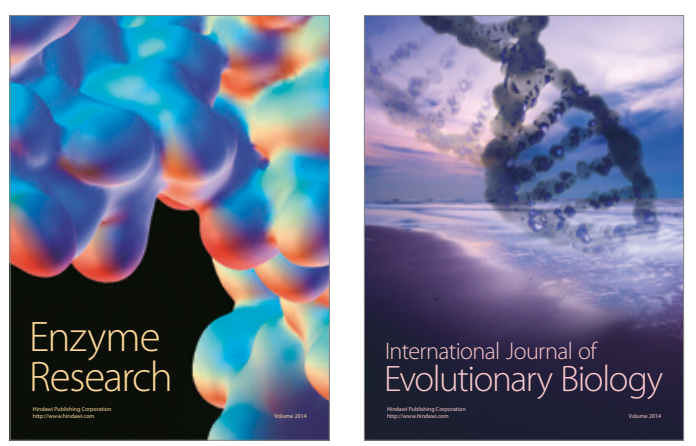
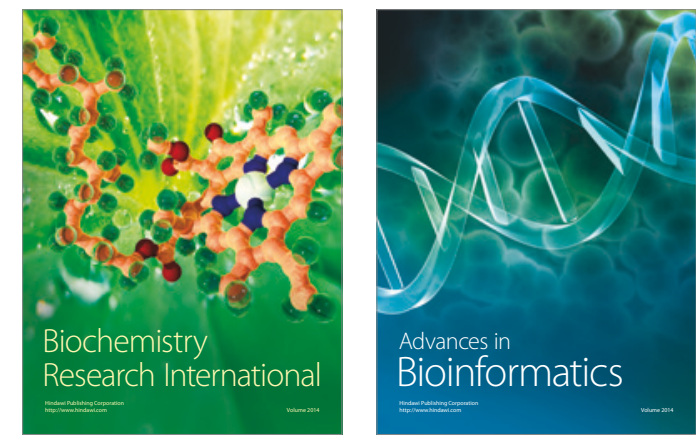

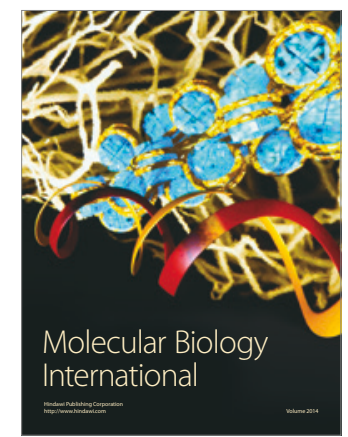

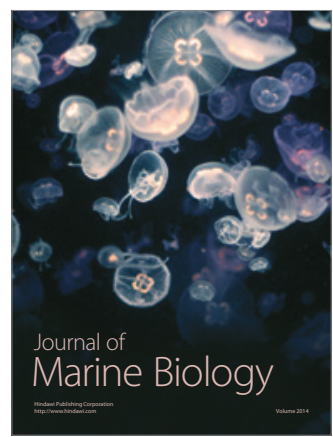

